International Journal of Scholarly Papers for Media and Communications

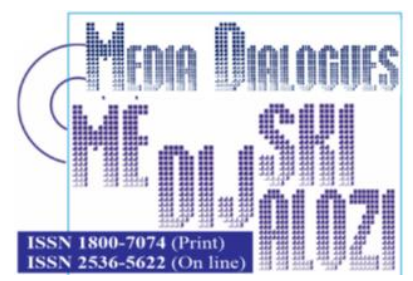

Draskovic, M., Ostasz, G. (2021), „Some Beliefs About Press Freedom”, Media Dialogues / Medijski dijalozi, Vol. 13, No. 3, pp. 45-53.

\title{
Some Beliefs About Press Freedom
}

\author{
Assoc. Prof. MIMO DRASKOVIC, \\ University of Montenegro, Maritime Faculty of Kotor, \\ Kotor, Montenegro, e-mail: rookie@t-com.me \\ Professor GRZEGORZ OSTASZ,
}

Rzeszow University of Technology, Department of humanities and social sciences, Rzeszow, Poland

\begin{tabular}{|c|c|}
\hline $\begin{array}{l}A R T I C L E \\
\quad I N F O\end{array}$ & $\begin{array}{c}\text { Received: Npovember 08, } 2019 \text { / Revised from: December 07, } 2019 \\
\text { Accepted: January 07, 2020 / }\end{array}$ \\
\hline DOI & $4254 / 1800-7074 / 13-3 / 4$ \\
\hline
\end{tabular}

\begin{abstract}
Improvement of human communication, and treating it as one of the basic unalienable human rights is a imprtant goal, but also the ultimate dream that not only preoccupies our present day communication and media researchers, but has historically concerned a lot of thinkers and philosophers. Arguably, this investigation originated in the seventeenth century when John Milton fought for liberty of the press and an end to government control over political and religious writings, thereby advocating for freedom of thought and speaking out against prepublication censorship. Further contributions to the debate were made by such philosophers as
\end{abstract}


John Locke, Voltaire, John Stuart Mill, John Dewey and Jürgen Habermas who investigated the ways of democratizing of modern media and emancipating the public sphere, and advocated for an undistorted communication. In the post-industrial (information) society like in the industrial society, freedom of expression is a right for every one. That right includes the right to freedom of doing research, and the right to receive and disseminate information and all sorts of ideas regardless of any boundaries and in any form and any way of his or her choice. That freedom includes in practice special duties and social responsibilities. Along with the other ICTs, the Internet is recognized as a global facilitor of information but its use should not be limited to journalism. Intellectual property, children's rights, cultural diversity, electronic commerce and international security need to be secured with the defined boundaries of the Universal Declaration of Human Rights and the other international resolutions adopted for that purpose and cyber criminality just like all other forms of crimes have to be fought.

KEYWORDS: Media regulation, information society, freedom of speech, right to communicate, Information and Communication Technologies.

\section{INTRODUCTION}

Already in the second half of the past century such insightful thinkers as Daniel Bell and Alvin Toffler discerned the beginnings of the transition from the industrial to the information level of social development. By the end of the 20th century and especially today this awareness has become almost universal. The question is now not whether the information society is real, but rather how to define its still forming structure, what are the contradictions that determine the dynamics of its development. The labor reserves that are left unengaged are distributed between services and information production. As a result, the production of information increases drastically.

The term "Information Society" came into use along with new information and communication technologies (ICTs) - internet, email, mobile phones — and generally refers to aspects of modern life that are shaped specifically by these. For instance, the term may be used to refer to a hoped-for future in which everyone has access to the internet; or to today's economic and trade systems which depend on the new ICTs for their speed and spread; or to economies in which information processing is responsible for a high proportionof the jobs and wealth created.

We cannot afford to forget about the mass media. Over the past 15 years, the media in most countries has both proliferated and become more liberal. While creating exciting opportunities for variety, inclusiveness and debate, commercial pressures which threaten these have also increased. Specific efforts are neededto encourage the media to address issues of public interest, including those affecting the 
poor and marginalised; otherwise, media content all over the world will become increasingly bland and meaningless.

Information and Communication Technologies (ICTs) have offered, since their advent, unprecedented opportunities for freedom of expression. But with their deve1-opment new legitimate interests have been identified. These could restrict that freedom but afford the information society a secure judicial foundation. The objective of any regulation is in general to make sure that the mechanism of any complex system works properly. For that reason, the regulation of the digital technologies is especially difficult because it implies a universal framework to regulate freedom of communication. The issue of regulating digital communication was raised with acuteness in the preparatory meetings of the Word Summit on the Information Society (WSIS).

The question was to find out if the means of information could be managed by standard regulation that is by article 19. of the Universal Declaration of Human Rights. In the information society as well as in the industrialized society, everyone has the right to freedom of expression. This freedom involves in practice special duties and social responsibilities and can then be submitted to some restrictions.

\section{THE NEW JUDICIAL ISSUES}

The issue of the legitimacy of the legislators' involvement of the legislator in the digital communication has been at the center of the debate between two schools in particular: the liberal school and the interventionist school. For the first, the only possible regulation is that of a free market, for the second, freedom should be regulated to allow respect of the national high values of society and secure a minimum of equity between rich and poor people.

\subsection{The Ultra Liberal Approach}

Those who believe in the ultra-liberal approach think that there is no reason why, in cyberspace, the media should be treated today differently from the past. It is believed that the regulations that were applied to the written press can regulate the free circulation of information on the internet. Today, the international community is entitled to reaffirm that access to new means of information and their use should have the same treatment for freedom of expression as the old means. It is not necessary to have special laws or rules to manage the content of the electronic press. The true international law for communication is secured by article 19. Any other law may restrict the right of individuals.

The protection of security should not, in any circumstances, become an excuse to restrict freedom of the press. Even the motives for violence should not be put forward in this context because there is a clear distinction between the dangers of vio- 
lence and the results of violence in information processing. According to this approach, violence should be shown with all its horrors. It is not normal that television or digital reports of wars should be censured on pretext that some people are sensitive. A global police of the Cyberspace would lead, inevitably, to the restriction of freedom of speech and freedom of the press and would be a danger to the free circulation of information in the world.

\subsection{The Interventionist Approach}

Against the ultra-liberal approach there is the interventionist approach which believes that the regulation of a free circulation of information on the Internet should not be limited to journalism and leave out the tremendous areas of application of the open networks in the field of culture and the electronic commerce. As a matter of fact, the deep changes that have revolutionized the digital sector have started giving great results which justify a preparation of a new judicial mechanism aiming at developing the different applications.

With the immaterial economy and the development of exchanges across borders, the protection of individuals from a misuse of the new technologies has become necessary. That protection should be used against the new cyber-crimes which consist in obtaining illegally credit cards numbers, stealing industrial secrets and having access to confidential public information. The question is to establish confidence between different actors, by favoring competition, securing a conclusive value of electronic documents, protecting consumers and the rights of intellectual property, ensuring the security of exchanges, anticipating criminal activities and above all facing any manipulation of information that tends to destabilize society. As a solution, the interventionist approach recommends a compromise between freedom of expression on one hand and social responsibility on the other.

As it had been suggested by the writers of a report on the ethics of information and published by the UNESCO in 2001, law is based on ethics: ethics are the only source of natural law, and natural law is the common law for humanity.

\subsection{The Legal Foundations of the Digital Technologies in the W.S.I.S (World Summit on the Information Society}

The recommendations of the UN and those of the WSIS are not constraining. Those who signed them had pledged, on the other hand, to respect them and take them into consideration. The legal dimension has then been at the vey foundation of the resolutions adopted by the WSIS. The Declaration of Principles adopted during the first phase of the WSIS in December 2003. included many issues related to information such as the access to the networks and the Internet governance. 


\subsection{The Human Rights and Freedom of Expression}

The issue of human rights and freedom of expression had priority over the discussions of the different preparatory phases of the Word Summit on the Information Society (WSIS). The Declaration of Principles has mainly stressed the importance of the right of everyone to freedom of expression and freedom of speech, of the preservation of fundamental values such as freedom, equality, solidarity, tolerance, the sharing of responsibilities and respect for the environment.

The Northern countries believed that these issues represented the main basis of the foundation of the information society. The Southern countries had insisted, on their part, upon the fact that human rights should necessarily include the right to full development and that freedom of expression should be submitted to the reservations mentioned in article 29 of the Universal Declaration in the same manner as in Article 19. After long dealings, a compromise was reached mentioning paragraphs 19 and 29 all together and in such a way that the engagement of States to respect the provisions of both articles at the same time.

\section{THE ABOLITION OF STATE MONOPOLY}

Some have tried but in vain to grant the media of all sorts a special importance by imposing them as a full partner in building the information society with the public sector, the private sector and civil society. But a consensus was easily reached when it was found necessary to favor the abolition of the State monopoly to 12 secure independence of the media and to allow professionals to produce norms and rules of conduct to do with digital information in practice.

\subsection{The Internet Governance}

When governments in the South requested to leave Internet governance with the United Nations and the international organizations concerned, the United States suggested discussing this issue in a different way with the participation of the private sector, a suggestion which implies that the status of The Internet Corporation for Assigned Names and Numbers (ICANN) would not change. But the representatives of the European Union who were then divided on the issue put it clearly that they would not let Americans be the only masters of Internet governance. They wanted a new model, one that would be more transparent and not be unilaterally controlled.

The requirements of security and fight against cyber-crimes including terrorism should not be a threat to the freedom of the press. Internet service-providers should not be taken responsible for the messages content they deliver. The ICANN should take into account the conclusions of this forum in a way that can preserve the reliability of information in its practiced technical mission. 


\subsection{Is regulation advisable?}

According to Cuilenburg and McQuail (2003), "historically, the state has often been perceived as the main enemy of freedom of individual expression, while at the same time it has also become, through constitutions and legal systems, the effective guarantor of freedom in important respects." As this statement underscores, there is much controversy regarding the level of involvement that regulatory instances should have in guaranteeing that the media carries out its social responsibilities. Different views of the debate span the spectrum from complete opposition to any formal regulation whatsoever (e.g. self-regulation by the media, with a reference to ethics codes as a normative framework internal to each media organization), to propositions for enforcement of social responsibility in media legislation.

However, regardless of the wide range of differing positions on what constitutes an acceptable level or intensity of regulation, most would agree that the media is obligated to carry out ethical practices, e.g. its social responsibility: "regardless of whether government-imposed public interest obligations are constitutional, the broadcast media, like the print media, have an ethical obligation to serve the public interest and make a positive contribution to the democratic process" (Napoli, 2001). It is worth exploring the different ways in which this ethical obligation can be carried out.

\subsection{Opting for self-regulation}

Anchored in Libertarian press theory with a solid grounding in the ideas of John Stuart Mill, the argument against regulation follows free market principles. Proponents of this view envision the media as a free marketplace of ideas. In line with this stance, one can argue that the natural tension in journalism, between the media's need to remain neutral and the pressure from groups within society to exert influence, 13 is not objectionable and simply needs to be well managed by the journalists themselves. According to this view, the existence of regulatory commissions, councils, ombudsmen or other frameworks are unnecessary: what we perceive as an accountability problem in the media is in fact "the natural and healthy tension created by journalistic autonomy in relation to various community groups." Following this perspective, "much of the debate on media accountability has focused on efforts to neutralize the tension between journalistic autonomy and the need for a responsible press. However, the nature of media accountability depends precisely on this conflict, which is not a dilemma to be solved but a healthy tension to be managed" (Plaisance, 2000).

Self-regulation is more or less effective depending on the individual journalist or media organization, and lies at the mercy of the media professionals' consciences. The most radical advocates of self-regulation argue for antinomianism, a form of non-ethics approach that opposes the implementation of any explicit rules. This view 
as- sumes that journalists make their decisions intuitively, spontaneously, and do not need regulation (Kova, 2008).

The basis of self-regulation in journalism lies in the existence of ethics codes, whose actual impact on ethical standards in media organizations is largely questionable-especially given that a certain portion of journalists are not fully aware of their content, and there is no formal structure to ethics code violations. The risk when dealing with ethics codes in journalism is to assume that their mere existence guarantees thorough application of ethical principles; one could maintain instead that the most effective formulation of an ethics code would take place not in writing, but ultimately through the status quo of what decisions and actions journalists perceive as being ethical and therefore carry out in the practice of their work.

Like many others in the field, Plaisance (2000) questions the reliability of ethical practices that are supposedly guaranteed by written ethics codes: "professional codes of ethics have become popular among news organizations as a demonstration of accountability. However, reliance on codes generates significant suspicion that they often are used to merely put an ethics veneer over questionable behavior". A similar idea was brought up during an Ethics and Human Rights in Information Society conference at UNESCO, by Rodotà (2007): Codes of ethics have been spawned in the most diverse sectors and feature, at times, considerable ambiguities. Indeed, some of them are ultimately little more than proclaims devoid of concrete effects and are only used to convey a reassuring image of the organizations that have drafted them. In this case, the implementation and effectiveness of ethics codes in practice depends on the individual journalists' attention to the significance of ethical reporting for their society. Whether they can carry out responsible journalism on their own, or on the contrary need a regulatory instance controlling them, remains largely subject to debate.

Some would argue that interest group pressures are such that the journalists are not independent in their editorial lines even if they strive to be, and thus need a juridical structure to back them in carrying out socially responsible decisions which 14 might not always comply with these pressures. A most central example is the commercial interest of their own news organization, which can easily conflict with the ability to carry out responsible journalism: "in other words, the media may be less likely to strive to uphold a 'self-imposed' responsibility to reflect the diversity of the communities they serve if it is more lucrative to shape content to satisfy commercial needs to reach certain fragmented audiences" (Plaisance, 2000).

\section{INSTEAD OF A CONCLUSION}

Media today have assumed tremendous importance. Every bit of our activity is not only reflected but also regulated and governed through press (media). Freedom of press aims at the freedom of speech and expression, which are the basic tenets of 
society. Media is a mighty institution wielding enormous powers and liability to the society, which are expected to be exercised for the protection and well-being of the people and limited. The moral responsibility of media is to foster liberty, justice, fraternity, peace and human rights in every society. Still media has been facing a perennial dilemma while discharging its rights, duties and obligation to continue that degree of liberty without which law is tyranny and with that degree of law without which liberty becomes licence.

Media with its intellectual vigour, analytical attitude and firm foresightedness can address, safeguard and resolve conflict between states, communities within the states in a multi-cultural society with ethnic diverse people, being a catalyst in the armed conflict and internal violence through mediation, negotiation and mutual consent providing energetic legislation against all form of discrimination and incitement to racial hatred and xenophobia of any organisation, group, party, institution or state that threatens multi-cultural democracy and ethnic peace of just, rational and humane society.

In a democratic world, credibility, utility and purpose of media are to import justice to the people and safeguard the rights and liberty of the people with integrity and steadfastness. Media can do miracles by fostering global security, addressing international arm trades, balance of power, nuclear weapons and non-military threats: such as terrorism, extremism, militia conspiracy and movements, strategic relationship of states and their foreign policy, etc.

And finally, it is the moral responsibility of media to produce a more just and peaceful world.

\section{BIBLIOGRAPHY}

Christians, C., Nordenstreng, K. (2007), "Social Responsibility Worldwide”, Journal of Mass Media Ethics, Vol. 1, No. 19, pp. 3-28.

Hodges, L. W. (1986), "Defining press responsibility: A functional approach" in D. Elliott (Ed.), Responsible journalism, pp 13-31.

Poler Kova, M., (2008), "Journalism Ethics in Multinational Family" in When in the EU, Should One Do as the EU Journalists Do?, University of Ljubljana, Ljubljana.

Napoli, Ph. (2001), "Social Responsibility and Commercial Broadcast Television: An Assessment of Public Affairs Programming in JMM", The International Journal on Media Management, Vol. 3, No. 4, pp. 226-233.

Owens-Ibie, N. (1994), "Press Responsibility and Public Opinion in Political Transition", Africa Media Review, African Council for Communication Education, Vol. 8, No. 1, pp. 121-129.

Plaisance, P. L. (2000), "The Concept of Media Accountability Reconsidered", Journal of Mass Media Ethics, Vol. 15, pp. 257-268. 
Rodotà, S. (2007), Ethics and Human Rights in the Information Society, UNESCO, pp. 13- 14.

Van Cuilenburg, J. J., McQuail, D., (2003), ”Media Policy Paradigm Shifts: Towards a New Communications Policy Paradigm", European Journal of Communication, Vol. 2, No. 18, pp. 181-207. 